\title{
Article \\ Hydrometallurgical Recycling Process for Mobile Phone Printed Circuit Boards Using Ozone
}

\author{
Silvie Brožová ${ }^{1} \mathbb{D}$, Magdalena Lisińska $^{2} \mathbb{D}$, Mariola Saternus $^{2} \mathbb{D}$, Bernadeta Gajda $^{3}$, \\ Gražyna Simha Martynková ${ }^{4}$ (i) and Aleš Slíva ${ }^{5, *(D)}$
}

1 Department of Non-Ferrous Metals, Refining and Recycling, VŠB-Technical University of Ostrava, 17. listopadu 15/2172, 70800 Ostrava-Poruba, Czech Republic; silvie.brozova@vsb.cz

2 Department of Metallurgy and Recycling, Faculty of Engineering Materials, Silesian University of Technology, Krasińskiego 8, 40-019 Katowice, Poland; magdalena.lisinska@polsl.pl (M.L.);

Mariola.Saternus@polsl.pl (M.S.)

3 Department of Metallurgy and Metal Technology, Faculty of Production Engineering and Materials Technology, Czestochowa University of Technology, Dąbrowskiego 69, 42-201 Częstochowa, Poland; bernadeta.gajda@pcz.pl

4 Nanotechnology Centre, CEET, VŠB-Technical University of Ostrava, 17. listopadu 15/2172, 70800 Ostrava-Poruba, Czech Republic; grazyna.simha@vsb.cz

5 Institute of Transport, Faculty of Mechanical Engineering, VŠB-Technical University of Ostrava, 17. listopadu 15/2172, 70800 Ostrava-Poruba, Czech Republic

* Correspondence: ales.sliva@vsb.cz; Tel.: +420-596-995-110

Citation: Brožová, S.; Lisińska, M.; Saternus, M.; Gajda, B.; Simha Martynková, G.; Slíva, A.

Hydrometallurgical Recycling Process for Mobile Phone Printed Circuit Boards Using Ozone. Metals 2021, 11, 820. https://doi.org/ $10.3390 /$ met11050820

Academic Editor: Jae-Chun Lee

Received: 1 April 2021

Accepted: 13 May 2021

Published: 18 May 2021

Publisher's Note: MDPI stays neutral with regard to jurisdictional claims in published maps and institutional affiliations.

Copyright: (c) 2021 by the authors. Licensee MDPI, Basel, Switzerland. This article is an open access article distributed under the terms and conditions of the Creative Commons Attribution (CC BY) license (https:// creativecommons.org/licenses/by/ $4.0 /)$.
Abstract: Printed circuit boards (PCBs) can be an important source of non-ferrous metals (Al, Sn, $\mathrm{Zn}$, and $\mathrm{Ni}$ ) and precious metals ( $\mathrm{Au}, \mathrm{Ag}, \mathrm{Cu}$, and $\mathrm{Pd})$. With the continuous increase in demand for metals due to the depletion of ores, recycling of this waste is becoming an attractive alternative. The printed circuits also contain hazardous metals, such as $\mathrm{Pb}, \mathrm{Hg}$, $\mathrm{As}$, and $\mathrm{Cd}$. Due to the huge increase in the amount of e-waste, the processing of printed circuit boards for metal recovery and proper handling of hazardous substances has a positive effect on the environment. Pyrometallurgical and hydrometallurgical methods are used for the treatment of this waste. Various oxidizing agents are used in the hydrometallurgical processes, including ozone. PCBs from mobile phones were assessed for the recovery of $\mathrm{Cu}, \mathrm{Sn}$, and precious metals. The ground and sieved materials were leached in nitric acid, hydrochloric acid, and sulfuric acid at various process parameters, such as leaching time, leaching agent, and temperature. It was found that the best result was obtained using hydrochloric acid with the addition of ozone at $353 \mathrm{~K}$ for a period of $4 \mathrm{~h}$ to obtain $68.45 \mathrm{~g} / \mathrm{dm}^{3}$ of copper. Preliminary results of electrolysis and cementation are also presented.

Keywords: hydrometallurgical process; ozone; acid leaching; metals recycling; e-waste

\section{Introduction}

The increasingly shorter life cycle of electrical and electronic devices forces society to frequently change these devices to new ones with different, better, and versatile functions. Consequently, old equipment waste is one of the fastest generated waste groups in the world [1]. Electronic waste (e-waste) includes any large or small electrical and electronic device that a user has disposed of or has somewhere at home. Televisions, desktops, washing machines, etc. are classified as large devices, while small devices include mobile phones, laptops, tablets, etc. [2]. Regardless of their size, most electronic devices contain a printed circuit board. This tile is a valuable element of each of these devices because it contains metals that are attractive in terms of recycling, including gold, silver, palladium, and copper [3]. In addition, there are hazardous metals, including lead and mercury, in printed circuits that can have a negative impact on the environment [4]. In other studies [5,6], hazardous cadmium, arsenic, chromium, and antimony were also identified in PCBs. The total composition of printed circuit boards has been analyzed by many 
researchers [7-12]. PCBs usually contain 40\% metals, 30\% plastics, and 30\% ceramic materials, although their actual composition varies depending on the intended use of the device. Printed circuit boards for mobile phones can therefore be considered as "city ores" for metal recovery. Some metals in PCBs may occur at much higher levels than in conventional ore deposits, making this waste a particularly interesting material for recycling [8]. Therefore, recycling is gaining importance also due to energy, cleanliness, and care for the environment. In turn, the storage and incineration of this waste generate dangerous products and gaseous emissions, which pose a serious threat to human health, the environment, and sustainable economic growth [13-15].

The basic techniques of recycling electronic waste are pyrometallurgical [16-19], hydrometallurgical [20-23], as well as bio-hydrometallurgical [24,25] methods in combination with mechanical pre-treatment. However, hydrometallurgical techniques are more precise, predictable, easy to control, require low capital costs and energy, and these methods have a lower impact on the environment compared to pyrometallurgical methods [19]. Recently, new technologies for recovering metals from e-waste have emerged, which are, among others, chelation technologies, ionic liquids, hybrid approach, and green adsorption [26]. Many results can be found in the literature describing the recovery of $\mathrm{Cu}$ from PCBs by hydrometallurgical methods. For leaching this waste, $\mathrm{H}_{2} \mathrm{SO}_{4}, \mathrm{HNO}_{3}, \mathrm{HCl}$, and aqua regia $\left(3 \mathrm{HNO}_{3}: 1 \mathrm{HCl}\right)$ were used, along with oxidants, which are $\mathrm{O}_{2}, \mathrm{Cl}_{2}, \mathrm{H}_{2} \mathrm{O}_{2}$, etc. [27]. Ozone, next to the oxidants, is a popular leaching agent that has the ability to react with metals, used among others to recover metals from ores.

Ozone with a standard redox potential of $2.07 \mathrm{~V}$ is known as one of the strongest oxidants in acidic solutions [27]. According to the literature, ozone is a stronger oxidant than oxygen. Table 1 shows a comparison of the oxidizing properties of selected reagents.

Table 1. Comparison of oxidizing properties of selected reagents adapted from [26].

\begin{tabular}{|c|c|c|c|c|c|c|c|}
\hline Reagents & Fluorine $\left(F_{2}\right)$ & Ozone $\left(\mathrm{O}_{3}\right)$ & $\begin{array}{c}\text { Hydrogen } \\
\text { Peroxide } \\
\left(\mathrm{H}_{2} \mathrm{O}_{2}\right)\end{array}$ & $\begin{array}{l}\text { Chlorine } \\
\left(\mathrm{Cl}_{2}\right)\end{array}$ & Oxygen $\left(\mathrm{O}_{2}\right)$ & $\begin{array}{c}\text { Bromine } \\
\qquad\left(\mathrm{Br}_{2}\right)\end{array}$ & Iodine $\left(I_{2}\right)$ \\
\hline $\begin{array}{c}\text { Redox } \\
\text { potential [V] }\end{array}$ & 2.87 & 2.07 & 1.78 & 1.36 & 1.23 & 1.09 & 0.54 \\
\hline
\end{tabular}

The use of ozone as an oxidant can be a reasonable alternative, giving a number of environmental benefits in the leaching process of concentrates and wastes that contain metals, including precious metals, mainly due to the formation of oxygen as the only by-product of the reaction [28]:

$$
\mathrm{O}_{3}+2 \mathrm{H}^{+}+2 \mathrm{e} \rightarrow \mathrm{O}_{2}+\mathrm{H}_{2} \mathrm{O}
$$

Another reason for using $\mathrm{O}_{3}$ is the ability to work under atmospheric pressure and room temperature [27]. Another advantage of ozone is that it can also be used as a leaching medium at very low solution concentrations $(\sim 10-4 \mathrm{M})$ by introducing the $\mathrm{O}_{2} / \mathrm{O}_{3}$ mixture at low-pressure $\mathrm{O}_{3}(<10 \mathrm{kPa})$ [28].

Ozone has been used, among others, as an oxidant in the leaching process of stibnite $\left(\mathrm{Sb}_{2} \mathrm{~S}_{3}\right)$ concentrates [28]. Antimony was extracted from a stibnite concentrate in a hydrochloric acid solution using $\mathrm{O}_{3}$. The $99 \%$ antimony was obtained as the result of oxidative leaching of the stibnite concentrate. The addition of ozone as an oxidizing agent was tested in studies on tetrahedrite $\left((\mathrm{Cu}, \mathrm{Fe}){ }_{12} \mathrm{Sb}_{4} \mathrm{~S}_{13}\right)$ leaching materials in $\mathrm{HCl}$ solutions [29]. The highest copper extraction efficiency was obtained in $0.5 \mathrm{M} \mathrm{HCl} \mathrm{(25 \% ),} \mathrm{while} \mathrm{in} \mathrm{the}$ case of antimony in $0.75 \mathrm{M} \mathrm{HCl}$, about $18 \%$. Ozone has also been used in research on pyrargyrite $\left(\mathrm{Ag}_{3} \mathrm{SbS}_{3}\right)$ [28]. Sulfuric acid with the addition of ozone was used, and an $80 \%$ silver dissolution rate was obtained. The experiment showed that ozone concentration has the greatest effect on silver leaching. Ozone was also successfully used in the hydrometallurgical gold recovery process-a preliminary treatment process with subsequent 
chlorate leaching [30] or before the conventional cyanide process [28]. Ozone was also used to process chalcopyrite [31]. The recycling of silver and zinc from metallic scraps was performed through ozone leaching at an ambient temperature and low $(\sim 0.1 \mathrm{M}) \mathrm{H}_{2} \mathrm{SO}_{4}$ concentration [32]. Ozone has also been used to leach antimony sulfide ore containing pyrite [33]. A high level of antimony extraction (94.3\%) with the low dissolution of Fe $(2.3 \%)$ was obtained using 4.5 M HCl. Ozone, in addition to being used as an oxidant in the leaching of metals from ores, can also be used for waste materials [34].

The positive results of the use of $\mathrm{O}_{3}$ for leaching of ores and other wastes presented in the literature have prompted us to undertake research and use this gas as an additional oxidizing agent in combination with acid to recover metals from PCBs by leaching.

The growing generation of e-waste and its hazardous nature has become a potential problem worldwide. Therefore, our attention has been focused on the hydrometallurgical processes for the recovery of metals from e-waste. The hydrometallurgical method opens new paths in the field of research, taking into account global development, growing demand, and the depletion of natural resources. The study observes the possibilities of the process to gain the maximum amount of reusable materials-metals from the PCBs. The effects of individual hydrometallurgical process parameters for the effective recovery of $\mathrm{Cu}$ and associated metals from the ground PCBs of used cell phones, such as the choice of leaching agent, the effect of temperature, and the effect of time were investigated.

\section{Materials and Methods}

Sixty-four pieces of used cell phones from various companies were used as the research material. In the beginning, manual disassembly of this waste was carried out, separating individual elements, such as housing, battery, screen, and other small elements from printed circuit boards. In the next step, these plates were cut with scissors into smaller pieces with a diameter of about 15-25 mm. The material prepared in this way was ground in a Retsch SK100 cross-flail mill (Retsch GmbH, Haan, Germany), equipped with 5 mm, $1 \mathrm{~mm}$, and $0.2 \mathrm{~mm}$ sieves. Multiple sieving of PCB material was used with decreasing diameter, and, finally, a material $<0.2 \mathrm{~mm}$ was obtained. The process of shredding PCBs was carried out for the purpose of effective metal recovery. The material prepared in this way, with a total weight of $750 \mathrm{~g}$, was subjected to leaching. Figure 1 presents the test stand.

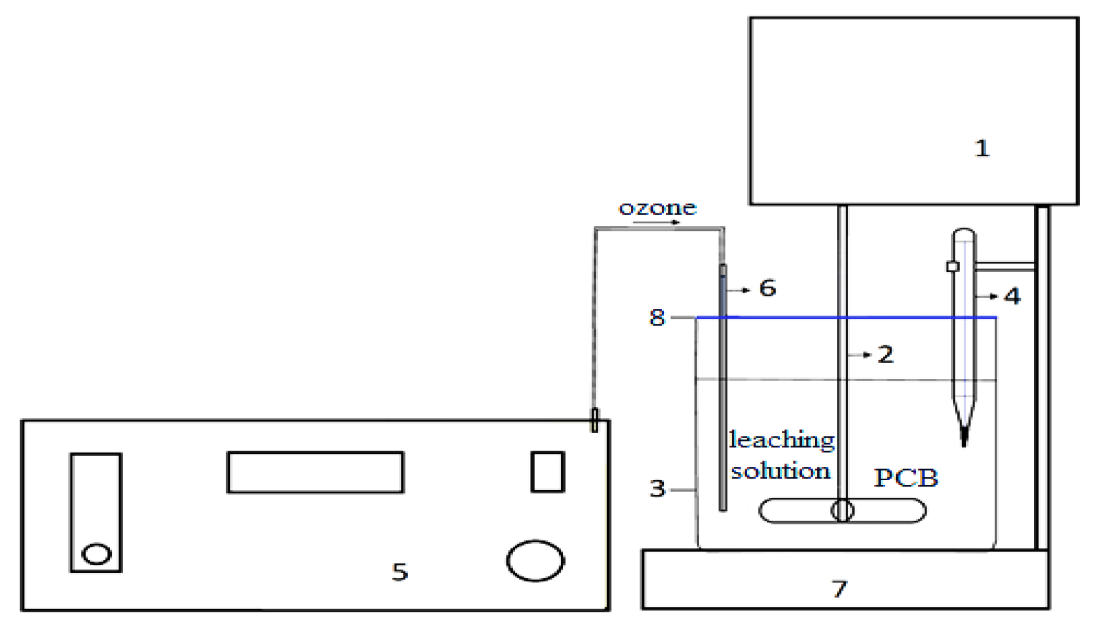

Figure 1. Scheme of leaching stand (1-mechanical agitator, 2 - glass agitator, 3 - glass beaker, 4thermometer, 5-ozone generator, 6-ozone introduction, 7-heating plate, and 8-system closure).

The elemental composition analysis of PCBs (Table 2) was performed using the semiquantitative method, the technique of X-ray fluorescence spectrometry with wavelength dispersion (WDXRF; Primus II X-ray fluorescence spectrometer from Rigaku, Japan ). 
Table 2. The elemental composition of spent PCB.

\begin{tabular}{ccccccccc}
\hline Element & Copper (Cu) & Tin (Sn) & Gold (Au) & Silver (Ag) & Aluminum (Al) & Zinc (Zn) & Iron (Fe) & Other \\
\hline Wt. $\%$ & 21.46 & 1.49 & 0.10 & 0.37 & 2.97 & 0.34 & 4.67 & 68.59 \\
\hline
\end{tabular}

The metal leaching efficiency was calculated and is attached in the Supplementary Materials of the article.

The leaching experiments were carried out in a $600 \mathrm{~mL}$ flask using $2 \mathrm{M}$ nitric acid, $2 \mathrm{M}$ sulfuric acid, and $2 \mathrm{M}$ hydrochloric acid as a leaching agent, as well as oxidants such as $30 \%$ hydrogen peroxide and ozone. Ozone was produced at a concentration of $140 \mathrm{mg} / \mathrm{dm}^{3}$, and the volume of the feed gas was $8 \mathrm{dm}^{3} / \mathrm{min}$, using a Korona L20 SPALAB generator (Korona, Parczew, Poland). The process was carried out at temperatures $298 \mathrm{~K}, 313 \mathrm{~K}$, and $353 \mathrm{~K}$, ensuring mixing of the system with a mechanical mixer (Adverti, Katowice, Poland) at $400 \mathrm{rpm}$. No mixing was used when $\mathrm{O}_{3}$ was used, which alone caused the system to move. The leaching process was carried out for $4 \mathrm{~h}$. The tests were carried out for a constant ratio of solids to liquids $(\mathrm{S} / \mathrm{L}=1: 4)$.

Samples of the individual solution were collected after $2 \mathrm{~h}$ and $4 \mathrm{~h}$ durations of the process. The diluted liquid samples were analyzed for copper, gold, silver, palladium, and tin content. The metal content of the sample was determined using microwave plasma atomic emission spectroscopy (MPAES) (Agilent MP-AES 4200, Agilent Technologies, Chicago, IL, USA). Preliminary cementation and electrolysis tests were also performed to separate copper from the solution. An analysis of the selected cementation was conducted through Hitachi S-4200 scanning electron microscope (Hitachi, Tokyo, Japan) using secondary electron detectors (SE). Chemical composition tests in powder microregions were performed using an X-ray energy dispersion spectrometer Noran System 7 (ThermoScientific, Waltham, MA, USA) at a voltage accelerating $15 \mathrm{kV}$ electron beam.

Figure 2 shows a diagram of the test steps carried out.

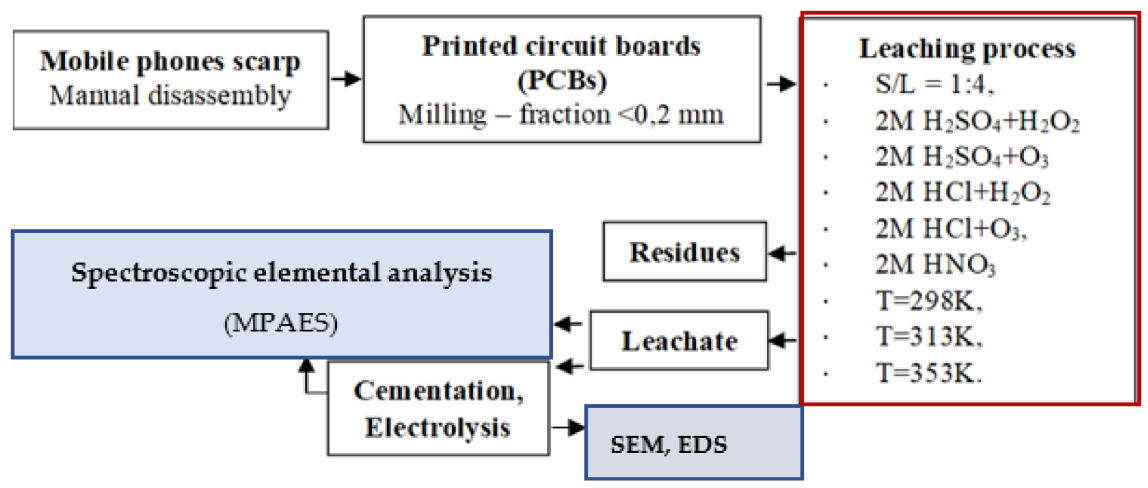

Figure 2. Scheme of the conducted research; the stages of leaching process of $\mathrm{Au}, \mathrm{Ag}, \mathrm{Pd}, \mathrm{Cu}$, and $\mathrm{Sn}$ from PCBs; and analysis of prepared samples.

\section{Results and Discussion}

\subsection{The Effect of Leaching Agent, Temperature, and Time on the Leaching Process}

The selection of the right leaching agent for maximum dissolution of the metal into the solution is very important and depends, among others, on factors such as the chemical and physical nature of the leached material, selectivity or the cost of the reagent, and its impact on the environment. Figure 3 shows the effect of time on copper concentration at $2 \mathrm{~h}$ and $4 \mathrm{~h}$ of leaching in $2 \mathrm{M}$ nitric acid and $2 \mathrm{M}$ hydrochloric acid, and with the addition of ozone and hydrogen peroxide at $298 \mathrm{~K}, 313 \mathrm{~K}$, and $353 \mathrm{~K}$. The histograms show the most efficient agents of the experiment. Copper can be directly oxidized to form copper (II) nitrate by dilute nitric acid $(\mathrm{V})$ at room temperature. Therefore, oxidants were only added to $\mathrm{H}_{2} \mathrm{SO}_{4}$ and $\mathrm{HCl}$ to increase the efficiency of $\mathrm{Cu}$ recovery. 


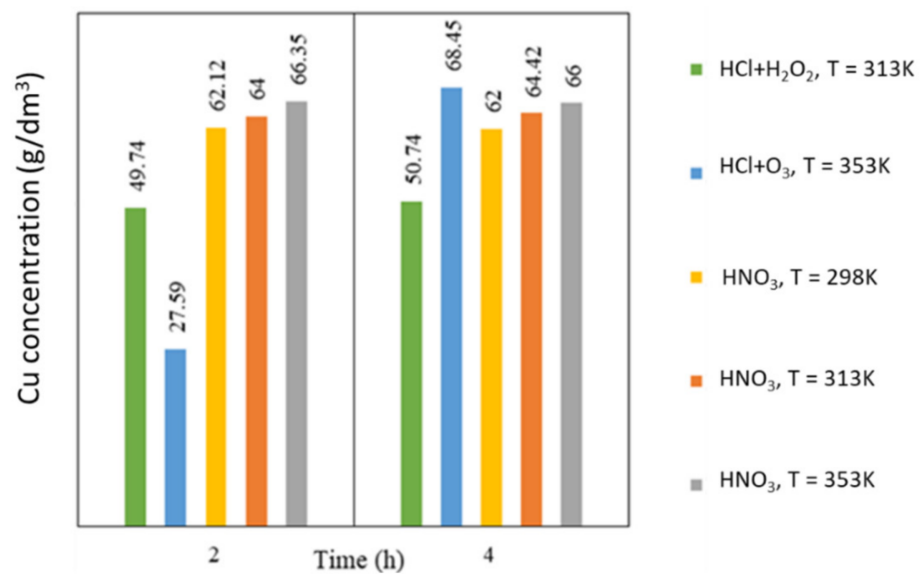

Figure 3. Copper concentration obtained after leaching in most efficient agents $-\mathrm{HNO}_{3}$ and $\mathrm{HCl}$ with the addition of $\mathrm{H}_{2} \mathrm{O}_{2}$ or $\mathrm{O}_{3}$ during $2 \mathrm{~h}$ and $4 \mathrm{~h}$.

Table 3 shows the copper concentration results obtained. The effect of time was observed for all sets of experiments. After $2 \mathrm{~h}$ of the experiment, an increase in copper concentration in the solution of over $10 \mathrm{~g} / \mathrm{dm}^{3}$ was observed. The lowest leached copper concentration after $2 \mathrm{~h}$ was obtained for mixtures $\mathrm{HCl}+\mathrm{O}_{3}$ and $\mathrm{H}_{2} \mathrm{SO}_{4}+\mathrm{O}_{3}$ at $298 \mathrm{~K}$ and $\mathrm{HNO}_{3}$ at $\mathrm{T}=353 \mathrm{~K}$. After adding $\mathrm{H}_{2} \mathrm{O}_{2}$ to $\mathrm{HCl}$ and $\mathrm{H}_{2} \mathrm{SO}_{4}$ and keeping the leaching time for $4 \mathrm{~h}$, the $\mathrm{Cu}$ concentration in the solution was similar or increased slightly $\left(\mathrm{HCl}+\mathrm{H}_{2} \mathrm{O}_{2}\right.$ at $\mathrm{T}=353 \mathrm{~K}$ increased by $6 \mathrm{~g} / \mathrm{dm}^{3}$ ).

Table 3. Copper concentration obtained after leaching in $\mathrm{HNO}_{3}, \mathrm{HCl}$, and $\mathrm{H}_{2} \mathrm{SO}_{4}$ with the addition of $\mathrm{H}_{2} \mathrm{O}_{2}$ or $\mathrm{O}_{3}$ within $2 \mathrm{~h}$ and $4 \mathrm{~h}$.

\begin{tabular}{|c|c|c|c|c|}
\hline \multirow{2}{*}{ Leaching Agent } & \multirow{2}{*}{$\begin{array}{l}\text { Additional } \\
\text { Oxidiser }\end{array}$} & \multirow{2}{*}{$\begin{array}{c}\text { Temperature } \\
{[\mathrm{K}]}\end{array}$} & \multicolumn{2}{|c|}{ Concentration $\left[\mathrm{g} / \mathrm{dm}^{3}\right]$} \\
\hline & & & $2 \mathrm{~h}$ & $4 \mathrm{~h}$ \\
\hline $\mathrm{HCl}$ & $\mathrm{H}_{2} \mathrm{O}_{2}$ & & 11.61 & 11.31 \\
\hline $\mathrm{H}_{2} \mathrm{SO}_{4}$ & $\mathrm{H}_{2} \mathrm{O}_{2}$ & & 10.97 & 8.26 \\
\hline $\mathrm{HCl}$ & $\mathrm{O}_{3}$ & 298 & 0.53 & 3.27 \\
\hline $\mathrm{H}_{2} \mathrm{SO}_{4}$ & $\mathrm{O}_{3}$ & & 0.48 & 2.01 \\
\hline $\mathrm{HNO}_{3}$ & - & & 62.18 & 62.00 \\
\hline $\mathrm{HCl}$ & $\mathrm{H}_{2} \mathrm{O}_{2}$ & & 49.74 & 50.76 \\
\hline $\mathrm{H}_{2} \mathrm{SO}_{4}$ & $\mathrm{H}_{2} \mathrm{O}_{2}$ & & 15.51 & 15.86 \\
\hline $\mathrm{HCl}$ & $\mathrm{O}_{3}$ & 313 & 9.92 & 25.86 \\
\hline $\mathrm{H}_{2} \mathrm{SO}_{4}$ & $\mathrm{O}_{3}$ & & 1.94 & 15.76 \\
\hline $\mathrm{HNO}_{3}$ & - & & 64.00 & 64.20 \\
\hline $\mathrm{HCl}$ & $\mathrm{H}_{2} \mathrm{O}_{2}$ & & 15.65 & 21.85 \\
\hline $\mathrm{H}_{2} \mathrm{SO}_{4}$ & $\mathrm{H}_{2} \mathrm{O}_{2}$ & & 10.73 & 10.26 \\
\hline $\mathrm{HCl}$ & $\mathrm{O}_{3}$ & 353 & 27.59 & 68.45 \\
\hline $\mathrm{H}_{2} \mathrm{SO}_{4}$ & $\mathrm{O}_{3}$ & & 2.51 & 5.70 \\
\hline $\mathrm{HNO}_{3}$ & - & & 66.35 & 66.00 \\
\hline
\end{tabular}

A noticeable increase in copper concentration in the solution after $4 \mathrm{~h}$ of leaching was observed when $\mathrm{O}_{3}$ and $\mathrm{H}_{2} \mathrm{O}_{2}$ were used. The best results of copper leaching during $4 \mathrm{~h}$ leaching were obtained for experiments at higher temperatures. For $2 \mathrm{M} \mathrm{HCl}+\mathrm{O}_{3}$ at $\mathrm{T}=353 \mathrm{~K}$ (the degree of copper leaching was $70 \%$ ) and $\mathrm{HNO}_{3}$ at $\mathrm{T}=313 \mathrm{~K}(74 \%)$ and $\mathrm{T}=353 \mathrm{~K}(79 \%)$, the results obtained were always above $60 \mathrm{~g} / \mathrm{dm}^{3}$. For $2 \mathrm{M} \mathrm{HCl}+\mathrm{H}_{2} \mathrm{O}_{2}$ at $\mathrm{T}=313 \mathrm{~K}$, the obtained result was $50 \mathrm{~g} / \mathrm{dm}^{3}$, but the degree of $\mathrm{Cu}$ leaching was $78 \%$.

As can be seen in Figure 3, the best copper leaching results were obtained with $\mathrm{HNO}_{3}$, which is a strong oxidant, and it was found that $\mathrm{HCl}$ with $\mathrm{O}_{3}$ and $\mathrm{H}_{2} \mathrm{O}_{2}$ addition has similar strong oxidizing properties for $\mathrm{Cu}$. 
Copper, as previously mentioned, reacts with nitric acid, in which the role of the oxidant is played by the nitrate ion, i.e., the ion of the acid residue, with the standard reaction potential for reducing this ion, e.g., to nitric oxide, being as much as $+0.96 \mathrm{~V}$. When an additional oxidant is added to $\mathrm{HCl}$, the standard potential also increases, which contributes to copper digestion.

Table 4 shows the results of tin concentration in $2 \mathrm{M}$ nitric acid, $2 \mathrm{M}$ sulfuric acid, and $2 \mathrm{M}$ hydrochloric acid with the addition of $30 \%$ hydrogen peroxide and ozone. It can be seen that the addition of hydrogen peroxide and ozone to $\mathrm{HCl}$ affected tin leaching in a similar manner. The exceptions are experiments at $\mathrm{T}=298 \mathrm{~K}$, where the tin leaching concentration was only $1.15 \mathrm{~g} / \mathrm{dm}^{3}\left(\mathrm{HCl}+\mathrm{O}_{3}\right)$.

Table 4. Tin concentration obtained after leaching in $\mathrm{HNO}_{3}, \mathrm{HCl}$, and $\mathrm{H}_{2} \mathrm{SO}_{4}$ with the addition of $\mathrm{H}_{2} \mathrm{O}_{2}$ or $\mathrm{O}_{3}$ within $2 \mathrm{~h}$ and $4 \mathrm{~h}$.

\begin{tabular}{ccccc}
\hline \multirow{2}{*}{ Leaching Agent } & $\begin{array}{c}\text { Additional } \\
\text { Oxidiser }\end{array}$ & $\begin{array}{c}\text { Temperature } \\
{[\mathbf{K}]}\end{array}$ & \multicolumn{2}{c}{ Concentration $\left[\mathbf{g} / \mathbf{d m}^{\mathbf{3}}\right]$} \\
\cline { 4 - 5 } & $\mathrm{H}_{2} \mathrm{O}_{2}$ & & $\mathbf{2} \mathbf{h}$ & $\mathbf{4} \mathbf{h}$ \\
\hline $\mathrm{HCl}$ & $\mathrm{H}_{2} \mathrm{O}_{2}$ & & 5.93 & 5.9 \\
$\mathrm{H}_{2} \mathrm{SO}_{4}$ & $\mathrm{O}_{3}$ & 298 & 0.18 & 0.26 \\
$\mathrm{HCl}$ & $\mathrm{O}_{3}$ & & 1.12 & 1.15 \\
$\mathrm{H}_{2} \mathrm{SO}_{4}$ & - & 0.43 & 0.44 \\
$\mathrm{HNO}_{3}$ & $\mathrm{H}_{2} \mathrm{O}_{2}$ & & - & - \\
$\mathrm{HCl}_{2}$ & $\mathrm{H}_{2} \mathrm{O}_{2}$ & & 0.38 & 9.86 \\
$\mathrm{H}_{2} \mathrm{SO}_{4}$ & $\mathrm{O}_{3}$ & 313 & 0.06 & 0.06 \\
$\mathrm{HCl}$ & $\mathrm{O}_{3}$ & & - & 10.41 \\
$\mathrm{H}_{2} \mathrm{SO}_{4}$ & - & & 0.18 & 0.32 \\
$\mathrm{HNO}_{3}$ & $\mathrm{H}_{2} \mathrm{O}_{2}$ & & - & - \\
$\mathrm{HCl}$ & $\mathrm{H}_{2} \mathrm{O}_{2}$ & & 2.09 & 10.63 \\
$\mathrm{H}_{2} \mathrm{SO}_{4}$ & $\mathrm{O}_{3}$ & 353 & 0.06 & 0.06 \\
$\mathrm{HCl}$ & $\mathrm{O}_{3}$ & & 11.17 & 12.00 \\
$\mathrm{H}_{2} \mathrm{SO}_{4}$ & - & & 0.07 & 0.45 \\
$\mathrm{HNO}_{3}$ & & & - & - \\
\hline
\end{tabular}

The best result was obtained with $\mathrm{HCl}+\mathrm{O}_{3}$ at $353 \mathrm{~K}$, which was $12 \mathrm{~g} / \mathrm{dm}^{3}$. An increase in temperature affects the dissolution of tin in these experiments. In turn, the addition of oxidants to $\mathrm{H}_{2} \mathrm{SO}_{4}$ did little to increase the tin concentration. The results obtained using sulfuric acid are from $0.06 \mathrm{~g} / \mathrm{dm}^{3}$ to $0.45 \mathrm{~g} / \mathrm{dm}^{3}$. The increase in temperature with $\mathrm{H}_{2} \mathrm{SO}_{4}$ had no effect on the dissolution of tin in the experiments. During $4 \mathrm{~h}$ of the experiment, no Sn cations were detected in the $2 \mathrm{M}$ nitric acid solution at $298 \mathrm{~K}, 313 \mathrm{~K}$, and $353 \mathrm{~K}$. The concentration might be very low below the detection limits of the equipment. In nitric acid, tin oxidizes to poorly soluble metastannic acid:

$$
3 \mathrm{Sn}+4 \mathrm{HNO}_{3}+\mathrm{H}_{2} \mathrm{O} \rightarrow 3 \mathrm{H}_{2} \mathrm{SnO}_{3}+4 \mathrm{NO}
$$

Figure 4 shows the best results obtained for tin concentration over $2 \mathrm{~h}$ and $4 \mathrm{~h}$.

Figure 5 shows the best results obtained for gold and silver concentrations over $4 \mathrm{~h}$. The best results of $\mathrm{Au}$ and $\mathrm{Ag}$ concentrations after $4 \mathrm{~h}$ of experiments were obtained at the highest temperature $\mathrm{T}=353 \mathrm{~K}$, using $\mathrm{HCl}+\mathrm{H}_{2} \mathrm{O}_{2}$ for $\mathrm{Au}$ and $\mathrm{HCl}+\mathrm{O}_{3}$ for $\mathrm{Ag}$ of $0.04 \mathrm{~g} / \mathrm{dm}^{3}$ and $0.21 \mathrm{~g} / \mathrm{dm}^{3}$, respectively. The results of the remaining experiments, which are not shown in the figure, were very low, not exceeding $0.01 \mathrm{~g} / \mathrm{dm}^{3}$ for both gold and silver. The low concentration of gold and silver indicates insufficient oxidizing properties of the leaching agents used. The presence of palladium in the solution was also investigated, but no positive results were obtained. 


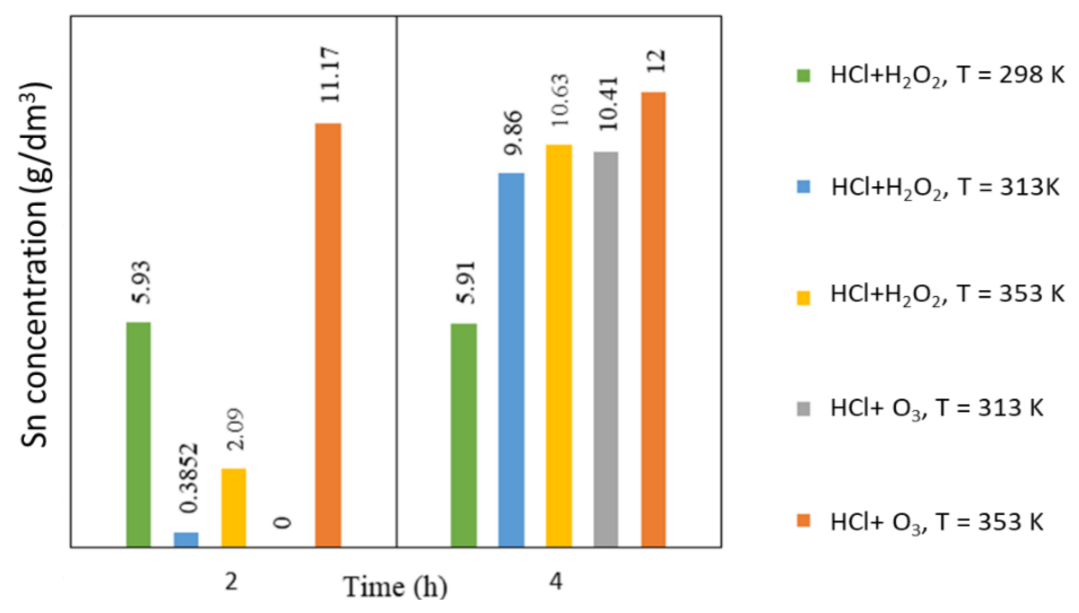

Figure 4. Tin concentration obtained after leaching in $\mathrm{HCl}$ with the addition of $\mathrm{H}_{2} \mathrm{O}_{2}$ or $\mathrm{O}_{3}$ during $2 \mathrm{~h}$ and $4 \mathrm{~h}$.
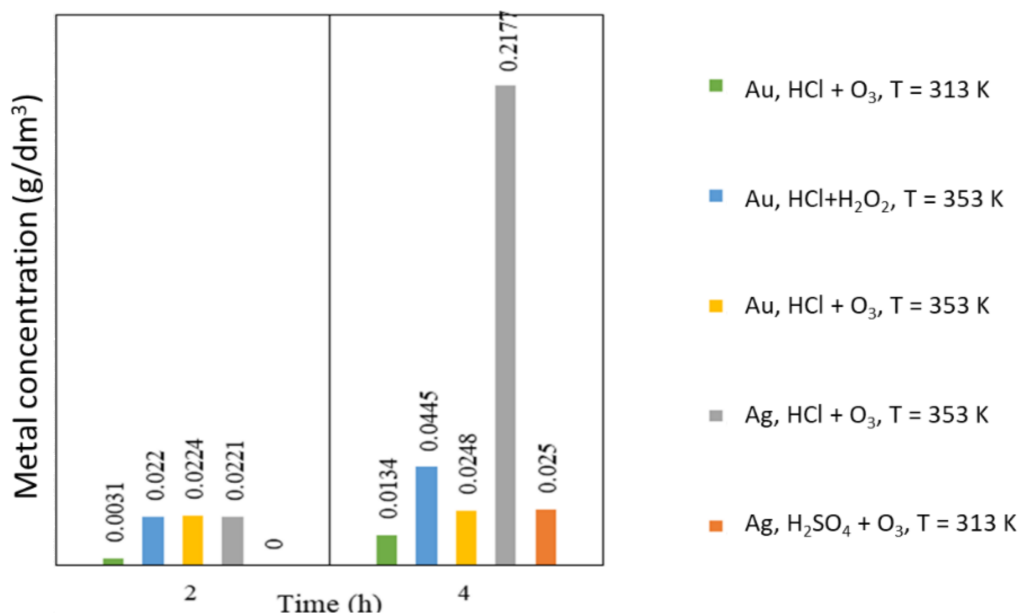

Figure 5. Gold and silver concentrations obtained after leaching in $\mathrm{HCl}$ and $\mathrm{H}_{2} \mathrm{SO}_{4}$ with the addition of $\mathrm{H}_{2} \mathrm{O}_{2}$ or $\mathrm{O}_{3}$ during $2 \mathrm{~h}$ and $4 \mathrm{~h}$.

\subsection{Cementation and Electrolysis}

For the initial tests of cementation and electrolysis, a cementing column and electrolyzer were used, which are part of the equipment of the hydrometallurgical laboratory VŠB-TU Ostrava. The purpose of cementation and electrolysis tests was to precipitate copper from the tested solution after PCB leaching experiments. Leach solutions in $2 \mathrm{M}$ sulfuric acid and $2 \mathrm{M}$ hydrochloric acid with $\mathrm{O}_{3}$ addition at $298 \mathrm{~K}$ were selected for cementation and electrolysis tests. In $2 \mathrm{M}$ nitric acid in the solution after leaching, a precipitate was formed, which made it impossible to carry out these tests. Preparation of solutions was carried out in a larger volume, i.e., $3 \mathrm{dm}^{3}$, for a solid ratio of solids to liquids $(S / L=1: 4)$ for $2 \mathrm{~h}$ (therefore, for safety reasons, tests at room temperature were selected). The $\mathrm{Cu}$ content in the solution before and after cementation/electrolysis was determined by microwave plasma atomic emission spectroscopy (MPAES).

The cementation test using a $1 \mathrm{dm}^{3}$ solution was carried out for $1 \mathrm{~h}$ at $80{ }^{\circ} \mathrm{C}$ and continuous mixing of the system. Iron was used to precipitate $\mathrm{Cu}$ during cementation. After the process, a metallic "powder" was obtained, which was examined for metal content by scanning microscopy. An electrolysis test was also carried out using a $1 \mathrm{dm}^{3}$ solution, also for $1 \mathrm{~h}$ at $25^{\circ} \mathrm{C}, 1.5 \mathrm{~A}$ intensity, and $1.4 \mathrm{~V}$ system voltage. Figure 6 shows a comparison of copper concentration in $\mathrm{HCl}+\mathrm{O}_{3}$ and $\mathrm{H}_{2} \mathrm{SO}_{4}+\mathrm{O}_{3}$ solution directly after leaching and in solutions after cementation and electrolysis tests. The best results obtained 
were selected. Result after cementation-24\% copper residue in $\mathrm{HCl}+\mathrm{O}_{3}$ solution, and after electrolysis-64\% copper residue in $\mathrm{H}_{2} \mathrm{SO}_{4}+\mathrm{O}_{3}$.

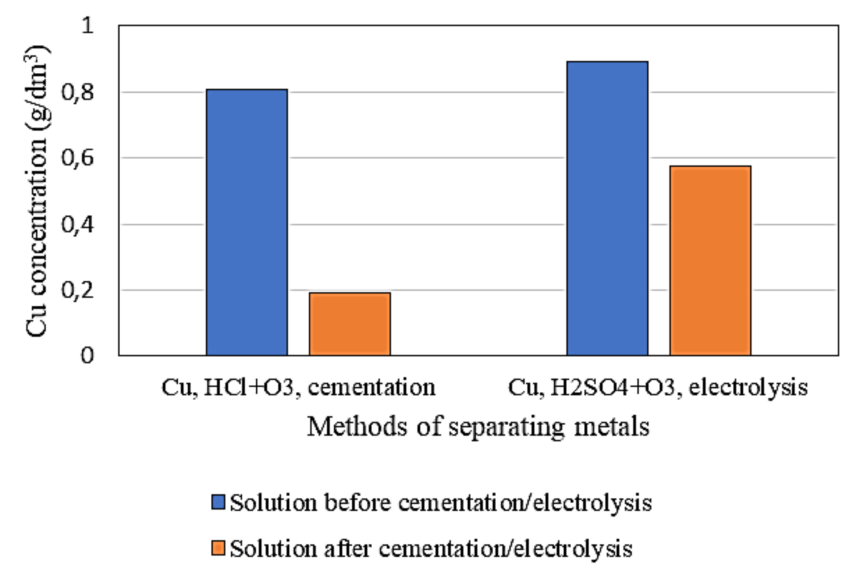

Figure 6. Comparison of copper content in the solution after leaching, collected before and after cementation and electrolysis.

Obtained "powder" samples after cementation were analyzed by means of a microanalysis EDS, obtaining the chemical composition and surface morphology. The tested materials have heterogeneous character and make it difficult to obtain accurate results; therefore, approximate contents can be obtained. The sample leached with $\mathrm{HCl}+\mathrm{O}_{3}$ mixture and after cementation was viewed using SEM together with the microanalysis of the chemical composition. Figure 7 shows the heterogeneous character of the cemented sample, with variable particle size and shape. For examination, two visibly different particles of the powdered sample were selected. Analysis at point 1 shows a light particle with a high content of various metals, while the particle analyzed at point 2 contains a high percentage of Fe. Dark particles are rare in the examined sample. The particles appearing white in the image have a majority over the sample; therefore, we can conclude that the dominant metal in the sample is copper.

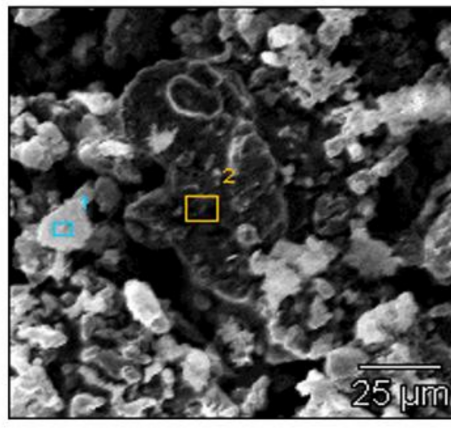

\begin{tabular}{lllllllll}
\hline EDS & $\mathrm{O}$ & $\mathrm{Si}$ & $\mathrm{P}$ & $\mathrm{V}$ & $\mathrm{Cr}$ & $\mathrm{Fe}$ & $\mathrm{Cu}$ & $\mathrm{Sn}$ \\
\cline { 2 - 6 } & \multicolumn{7}{c}{ weight, $\%$} \\
\hline
\end{tabular}

\begin{tabular}{lcccccccc}
\hline Point 1 & 7.4 & 1.0 & 0.4 & 1.1 & 1.2 & 26.2 & 50.2 & 12.6 \\
Point 2 & 4.7 & 0.2 & - & - & - & 92.6 & 2.5 & - \\
\hline
\end{tabular}

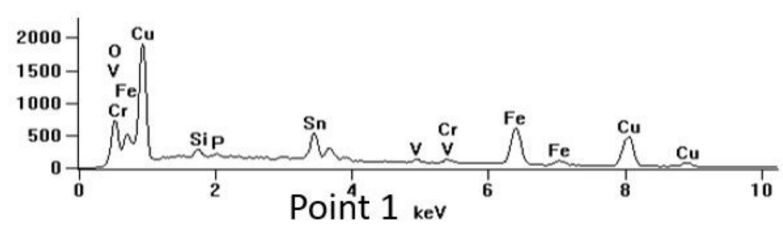

Figure 7. SEM image and EDS elemental analysis for a sample with $\mathrm{HCl}+\mathrm{O}_{3}$ after cementation.

After leaching of the PCB, many metals are present in the solution that can hinder the separation of copper from the solution during cementation/electrolysis. Attempts should be made to remove individual metals so that the copper can be separated completely. Therefore, the method of recovering $\mathrm{Cu}$ from a solution requires the continuation of research.

\section{Conclusions}

The leaching process of printed circuit boards was carried out using acid mixtures with ozone known for strong oxidizing properties and the ability to react with metals. The 
conducted research indicates the high potential of the PCB leaching method using $\mathrm{HCl}$ with the addition of $\mathrm{O}_{3}$. The best results for copper in the $4 \mathrm{~h}$ leaching process were observed when using $2 \mathrm{M}$ hydrochloric acid and ozone at $\mathrm{T}=353 \mathrm{~K}(70 \%)$ and $2 \mathrm{M}$ hydrochloric acid and hydrogen peroxide at $\mathrm{T}=313 \mathrm{~K}(78 \%)$. The addition of oxidants to hydrochloric acid has a positive effect on the tin recovery of $100 \%$. Excellent copper leaching results were also observed with $\mathrm{HNO}_{3}$, but this acid does not contribute to the dissolution of tin and other metals tested. The disadvantage of this leaching agent is also NO formation, which is why all experiments must be carried out in a closed system. Another disadvantage is the difficulty of filtering the solution to be analyzed for metal content due to the formation of a large precipitate.

In the case of $\mathrm{Au}$ and $\mathrm{Ag}$, the addition of hydrogen peroxide and ozone to sulfuric acid and hydrochloric acid did not significantly increase their concentration in the solution after the leaching process. However, a minimal increase in the gold and silver concentrations was observed for experiments using hydrochloric acid with the addition of oxidants (Au for $\mathrm{HCl}+\mathrm{H}_{2} \mathrm{O}_{2}$ at $\mathrm{T}=353 \mathrm{~K}$ and $\mathrm{Ag}$ for $\mathrm{HCl}+\mathrm{O}_{3}$ at $\mathrm{T}=353 \mathrm{~K}$ ). Preliminary cementation and electrolysis tests require further testing. Continued research on ozone leaching will allow us to recognize the phenomena occurring in this process and select the appropriate parameters for effective recovery of metals from printed circuit boards.

Supplementary Materials: The following are available online at https:/ / www.mdpi.com/article/10 .3390/met11050820/s1.

Author Contributions: Conceptualization, S.B. and M.L.; methodology, M.S.; validation, S.B., G.S.M. and A.S.; formal analysis, B.G.; investigation, S.B.; resources, M.L.; data curation, B.G.; writingoriginal draft preparation, M.L.; writing—review and editing, M.L. and G.S.M.; supervision, A.S. and S.B.; funding acquisition, S.B. All authors have read and agreed to the published version of the manuscript.

Funding: This research was funded by grant number SS01020312, MEYS SP2021/106 and SP2021/53, project innovative and additive manufacturing technology-new technological solutions for $3 \mathrm{~d}$ printing of metals and composite materials, reg. no. CZ.02.1.01/0.0/0.0/17_049/0008407 financed by structural founds of EU.

Institutional Review Board Statement: Not applicable.

Informed Consent Statement: Not applicable.

Data Availability Statement: Not applicable.

Conflicts of Interest: The authors declare no conflict of interest.

\section{References}

1. Cui, H.; Anderson, C.G. Literature Review of Hydrometallurgical Recycling of Printed Circuit Boards (PCBs). J. Adv. Chem. Eng. 2016, 6, 142-153.

2. Directive 2012/12/EU of the European Parliament and of the Council of 4 July 2012. on Waste Electrical and Electronic Equipment (WEEE). Official Journal of the European Union. 2012. Available online: https://eur-lex.europa.eu/legal-content/EN/TXT/PDF/ ?uri=CELEX:32012L0019\&from $=$ EN (accessed on 16 May 2021).

3. Woynarowska, A.; Żukowski, W. Współczesne Metody Recyklingu Odpadów Elektronicznych, Technical Transactions. Chemistry 2012, 109, 176-185. Available online: https:/ / repozytorium.biblos.pk.edu.pl/redo/resources/31565/file/suwFiles / WoynarowskaA_WspolczesneMetody.pdf (accessed on 16 May 2021).

4. Williams, P.T. Valorizations of Printed Circuit Boards from Waste Electrical and Electronic Equipment by Pyrolysis. Waste Biomass Valor. 2010, 1, 107-120. [CrossRef]

5. Goosey, M.; Kellner, R. A Scoping Study: End-of-Life Printed Circuit Boards; Intellect and the Department of Trade and Industry: London, UK, 2002.

6. Hall, W.J.; Williams, P.T. Separation and recovery of materials from scrap printed circuit boards. Resour. Conserv. Recycl. 2007, 51, 691-709. [CrossRef]

7. Yamane, L.H.; de Moraes, V.T.; Espinosa, D.C.; Tenório, J.A. Recycling of WEEE: Characterization of spent printed circuit boards from mobile phones and computers. Waste Manag. 2011, 31, 2553-2558. [CrossRef] [PubMed]

8. Ficeriová, J.; Baláž, P.; Gock, E. Leaching of gold, silver, and accompanying metals from circuit boards (PCBs) waste. Acta Montan. Slovaca 2011, 16, 128-137. 
9. Rao, M.D.; Singh, K.K.; Morrison, C.A.; Love, J.B. Recycling copper and gold from e-waste by a two-stage leaching and solvent extraction process. Separ. Purif. Technol. 2021, 263, 118400. [CrossRef]

10. Rao, M.D.; Singh, K.K.; Morrison, C.A.; Love, J.B. Challenges and opportunities in the recovery of gold from electronic waste. RSC Adv. 2020, 10, 4300-4309. [CrossRef]

11. Silva, L.H.d.S.; Júnior, A.A.F.; Azevedo, G.O.A.; Oliveira, S.C.; Fernandes, B.J.T. Estimating Recycling Return of Integrated Circuits Using Computer Vision on Printed Circuit Boards. Appl. Sci. 2021, 11, 2808. [CrossRef]

12. Ahirwara, R.; Tripathi, A.K. E-waste management: A review of recycling process, environmental and occupational health hazards, and potential solutions. Environ. Nanotechnol. Monit. Manag. 2021, 15, 100409.

13. Park, Y.J.; Fray, D.J. Recovery of high purity precious metals from printed circuit boards. J. Hazard. Mater. 2009, 164, 1152-1158. [CrossRef]

14. Yang, T.; Xu, Z.; Wen, J.; Yang, L. Factors influencing bioleaching copper from waste printed circuit boards by Acidithiobacillus ferrooxidans. Hydrometallurgy 2009, 97, 29-32. [CrossRef]

15. Dutta, D.; Panda, R.; Kumari, A.; Goel, S.; Jha, M.K. Sustainable recycling process for metals recovery from used printed circuit boards (PCBs). Sustain. Mater. Technol. 2018, 17, 1-9. [CrossRef]

16. Antrekowitsch, H.; Potesser, M.; Spruzina, W.; Prior, F. Metallurgical Recycling of Electronic Scrap. In Proceedings of the EPD Congress, San Antonio, TX, USA, 12-16 March 2006; pp. 12-16.

17. Ari, V. A Review of Technology of Metal Recovery from Electronic Waste; Book Chapter 6; InTech: Rijeka, Croatia, 2016 ; pp. 122-158.

18. Shuey, S.A.; Taylor, P. A Review of Pyrometallurgical Treatment of Electronic Scrap. In Proceedings of the SME Annual Meeting, Denver, CO, USA, 23-25 February 2004; pp. 23-25.

19. Guo, Q.; Yue, X.; Wang, M.; Liu, Y. Pyrolysis of scrap printed circuit board plastic particles in a fluidized bed. Powder Technol. 2010, 198, 422-428. [CrossRef]

20. Brožová, S.; Lisinska, M.; Saternus, M.; Rigoulet, H.; Zbránková, M. Efficiency of leaching of used PCBs using different acids. In Proceedings of the International Multidisciplinary Scientific GeoConference Surveying Geology and Mining Ecology Management, SGEM, Albena, Bulgaria, 28 June-7 July 2019; Volume 19, pp. 695-702, ISSN: 13142704.

21. Sheng, P.P.; Etsell, T.H. Recovery of gold from computer circuit board scrap using aqua regia. Waste Manag. Res. 2007, 25, 380-383. [CrossRef]

22. Quinet, P.; Proost, J.; van Lierde, A. Recovery of precious metals from electronic scrap by hydrometallurgical processing routes. Miner. Metall. Process. 2005, 22, 17-22. [CrossRef]

23. Tuncuk, A.; Stazi, V.; Akcil, A.; Yazici, E.Y.; Devici, H. Aqueous metal recovery techniques from e-scrap: Hydrometallurgy in recycling. Miner. Eng. 2012, 25, 28-37. [CrossRef]

24. Harikrushnan, B.; Shreyass, G.; Hemant, G.; Pandimadevi, M. Recovery of Metals from Printed Circuit Boards (PCBs) Using a Combination of Hydrometallurgical and Biometallurgical Processes. Int. J. Environ. Res. 2016, 10, 511-518.

25. Wu, W.; Liu, X.; Zhang, X.; Zhu, M.; Tan, W. Bioleaching of copper from waste printed circuit boards by bacteria-free cultural supernatant of iron-sulfur-oxidizing bacteria. Bioresour. Bioproces. 2018, 5, 1-13.

26. Moodley, S.J. The Evaluation of Ozone Technology to Reduce the Concentration of Polychlorinated Biphenyls (PCBs) in Contaminated Soil. Master's Thesis, Faculty of Engineering, University of Kwa-Zulu Natal, Durban, South Africa, 2011. Available online: http:/ / hdl.handle.net/10413/5095 (accessed on 27 February 2021).

27. Tian, Q.; Wang, H.; Xin, Y.; Yang, Y.; Li, D.; Guo, X. Effect of selected parameters on stibnite concentrates leaching by ozone. Hydrometallurgy 2016, 165, 295-299. [CrossRef]

28. Viñals, J.; Juan, E.; Roca, A.; Cruells, M.; Casado, J. Leaching of metallic silver with aqueous ozone. Hydrometallurgy 2005, 76, 225-232. [CrossRef]

29. Ukasik, M.; Havlik, T. Effect of selected parameters on tetrahedrite leaching by ozone. Hydrometallurgy 2005, 77, 139-145. [CrossRef]

30. Van Antwerp, W.P.; Lincoln, P.A. Precious Metal Recovery Using UV Ozone. U.S. Patent 4642134, 2 October 1987.

31. Havlík, T. Microwave leaching of chalcopyrite-Possible improvement in Hydrometallurgy. Metal 2010, 64, 25-28.

32. Brožová, S.; Drápala, J.; Kursa, M.; Pustějovská, P.; Jursová, S. Leaching refuse after sphalerite mineral for extraction zinc and cobalt. Metalurgija 2016, 55, 497-499.

33. Tian, Q.; Wang, H.; Xin, Y.; Li, D.; Guo, X. Ozonation leaching of a complex sulfidic antimony ore in hydrochloric acid solution. Hydrometallurgy 2016, 159, 126-131. [CrossRef]

34. Jursová, S.; Pustějovská, P.; Brožová, S. Study on reducibility and porosity of metallurgical sinter. Alex Eng. J. 2018, 57, 1657-1664. [CrossRef] 